\title{
Identifikasi Potensi Predator dan Hama pada Peternakan Kelulut (Hymenoptera; Apidae; Meliponini; Tetragonula, Lepidotrigona) melalui Pengamatan Cepat di Kabupaten Padang Pariaman, Sumatera Barat
}

\section{Identification of Potential Predators and Pests in Stingless Bee Farm (Hymenoptera; Apidae; Meliponini; Tetragonula, Lepidotrigona) through Rapid Observation in Padang Pariaman Regency, West Sumatra}

\author{
MUHAMMAD NAZRI JANRA ${ }^{*}$, HENNY HERWINA ${ }^{1}$, SITI SALMAH ${ }^{1}$, RUSDIMANSYAH $^{2}$, JASMI $^{3}$ \\ ${ }^{1}$ Jurusan Biologi, Fakultas Matematika dan Ilmu Pengetahuan Alam, Universitas Andalas, Jalan Kampus Unand \\ Limau Manis Pauh Padang, Sumatera Barat 25163, Indonesia \\ ${ }^{2}$ Program Studi Peternakan, Fakultas Peternakan Universitas Andalas, Jalan Kampus Unand Limau Manis Pauh \\ Padang, Sumatera Barat 25163, Indonesia \\ ${ }^{3}$ Sekolah Tinggi Ilmu Kesehatan Indonesia, Jalan Khatib Sulaiman No. 17, Padang, Sumatera Barat, 25173, \\ Indonesia
}

Diterima 26 Juli 2020/Disetujui 3 Desember 2020

\begin{abstract}
Stingless bees have been considered as the excellent option in the apiary sector as they produce valuable products such as honey, bee pollen and wax. Apiary business with stingless bee at its core has shown progressive increment especially in West Sumatra. Therefore, to maximize the production of the stingless bee apiary, knowing detrimental predator or pest organisms as well as the way of managing them are essential. This article described potential predators and pests of stingless bee identified through rapid observation conducted on 14 April 2019 at a community apiary in Padang Pariaman Regency, West Sumatra. There were 17 predators and pests identified, consist of six bird species, five odonate species and six ant species. The predation, competition and disadvantage possibly emerge from the existence of these organisms around stingless bee apiary are discussed, along with the feasible mitigation effort.
\end{abstract}

Key words: bird, mitigation, odonate, stingless bee

\section{PENDAHULUAN}

Lebah tanpa sengat (stingless bee), yang dikenal juga dengan nama lokalnya kelulut, galo-galo, klanceng atau teuweul, adalah kelompok serangga sosial yang berasal dari beberapa marga seperti Tetragonula, Lepidotrigona, Geniotrigona atau Heterotrigona; semuanya tergabung ke dalam tribe (suku) Meliponini dan bangsa Hymenoptera bersama-sama dengan semut, lebah serta penyengat (Sihombing 2005; Syafrizal et al. 2012). Di Indonesia sampai saat ini tercatat sekitar 37 jenis kelulut yang sebagian besar di antaranya dapat dimanfaatkan untuk mendapatkan madu serta produk lainnya (Balai Penelitian dan Pengembangan Teknologi Hasil Hutan Bukan Kayu 2018).

*Penulis korespondensi:

E-mail:mnjanra@sci.unand.ac.id
Sebagai serangga sosial, koloni kelulut terdiri dari seekor ratu, beberapa ratus lebah jantan serta ribuan individu lebah pekerja (Michener 2007). Masing-masing kasta dapat dibedakan melalui bentuk morfologinya, terutama dari ukuran tubuh. Ratu menjaga populasi koloni melalui perkawinan dengan pejantan diikuti dengan peneluran yang dilakukan secara terus menerus, termasuk juga menghasilkan calon-calon ratu baru yang akan membentuk koloninya sendiri (Sumoprastowo dan Suprapto 1980). Lebah pekerja melakukan beragam fungsi seperti mencari makan untuk seluruh anggota koloni, memelihara telur dan larva, menjaga kondisi ideal di dalam sarang termasuk mengorbankan diri untuk menjaga keselamatan sarang dari gangguan hewan-hewan pengganggu (Michener 2007). 
Kelulut sebagai penghasil madu berbeda dari lebah madu biasa (Apis spp.), yaitu tidak mempunyai sengat dan membela diri dengan cara menggigit saat terganggu oleh hewan lain (Syafrizal et al. 2012). Selain itu, beberapa mekanisme juga telah dikembangkan oleh kelulut sebagai cara bertahan dari hewan pemangsa. Antara lain dengan menggunakan semacam senyawa kimia berupa resin yang lengket untuk menghalau gangguan semut (Lehmberg et al. 2008), modifikasi ukuran dan bentuk struktur lubang masuk sarang (Couvillon et al. 2007; Grüther et al. 2011) atau dengan meningkatkan suhu sarang saat terjadi gangguan atau serangan (Hilário dan ImperatrizFonseca 2003).

Secara umum, hama pengganggu pada sarang dan koloni kelulut yang pernah tercatat dan dipublikasikan antara lain semut (Lehmberg et al. 2008), gajah hutan, simpanse, serta musang (Estienne et al. 2016), beragam jenis burung, serangga pemangsa (assassin bug) dan laba-laba (Wattanachaiyingcharoen dan Jongjitvimol 2007; Premila et al. 2013). Kelabang Scolopendra hardwicki teramati memangsa pekerja dan ratu dari kelulut Trigona iridipennis di India (Vijayakumar et al. 2012), sedangkan serangan caplak Pyemotes tritici dilaporkan menghancurkan beberapa koloni kelulut yang dipelihara di Amerika Selatan (Manezes et al. 2009). Di Indonesia, belum banyak dipublikasikan mengenai organisme yang berperan sebagai predator atau hama bagi koloni kelulut. Dengan makin banyaknya kegiatan peternakan dan perbiakan kelulut yang dilakukan untuk mendapatkan madu dan produk lainnya, maka sangat penting untuk memaksimalkan pengelolaan yang dilakukan. Di dalam tulisan ini dibahas mengenai jenis-jenis hewan yang diperkirakan berpotensi sebagai pemangsa dan hama terhadap kelulut yang teramati di salah satu peternakan di Sumatera Barat.

\section{BAHAN DAN METODE}

Lokasi Pengamatan. Pengamatan dilakukan pada peternakan kelulut yang dikelola oleh Kelompok Tani Sakato Palak Juha yang ada di Kenagarian Lurah Ampalu, Kabupaten Padang Pariaman (koordinat lokasi $0^{\circ} 33$ '26" LS, $100^{\circ} 9^{\prime} 30^{\prime \prime} \mathrm{BT}$, ketinggian 4 meter dari permukaan laut) pada tanggal 14 April 2019. Terdapat kurang lebih 20 kotak pemeliharaan berisi koloni kelulut dari marga Tetragonula dan Lepidotrigona yang diletakkan di bawah kanopi pepohonan budidaya (Gambar 1) yang didominasi oleh durian (Durio zibethinus), kelapa (Cocos nucifera), nangka (Arthocarpus spp.) dan jengkol (Pithecelobium spp.). Pada lokasi ini juga ditumpangkan beberapa koloni lebah madu (Apis cerana) yang sengaja dipelihara dalam lokasi yang sama dengan koloni kelulut tersebut.

Pengoleksian Data di Lapangan dan Identifikasi Spesimen. Pengamatan jenis-jenis hewan predator dan hama pada peternakan kelulut disesuaikan dengan jenis taksa yang ada. Untuk burung, pengamatan dilakukan dengan metoda Daftar Jenis MacKinnon dimana jenis yang terlihat diindentifikasi dan kemudian dicatat di dalam tabel daftar jenis (MacKinnon dan Phillipps 1993; MacKinnon et al. 2010). Untuk pengamatan ini, jumlah catatan jenis maksimal per tabel dimodifikasi menjadi 10 jenis dari total maksimal 20 jenis per tabel yang biasa digunakan untuk pengamatan pada kawasan yang luas. Dengan demikian, pengamatan dapat lebih terakomodasi pada kawasan peternakan kelulut yang tidak terlalu luas. Tidak boleh ada jenis burung yang sama dicatat dua kali dalam tabel yang sama, jenis tersebut jika teramati bisa dicatat ulang di dalam tabel berikutnya setelah tabel sebelumnya penuh. Sebagai tambahan, keberadaan jenis burung juga dideteksi melalui suara atau tanda-tanda lainnya seperti sarang dan bulu yang jatuh. Untuk serangga, dalam hal ini capung dan semut, digunakan metoda tersendiri. Capung yang terdapat di sekitar lokasi peternakan kelulut diamati menggunakan teknik fotografi tanpa mengoleksi spesimen sesuai dengan Janra (2018) dan diidentifikasi dengan menggunakan Bárta dan Dolny் (2013); Setiyono et al. (2017); dan Haliaster (2018). Semut dikoleksi dengan menggunakan metoda hand-collection dan baited trap (Rizali et al. 2008; Wielgoss et al. 2010) untuk kemudian diidentifikasi dengan menggunakan Bolton (1994) dan Hashimoto (2003). Interaksi langsung yang dilakukan oleh kelompok hewan tersebut di atas terhadap koloni kelulut, jika terlihat di lapangan, dicatat untuk digunakan dalam menentukan potensinya sebagai predator, hama atau lainnya.

Analisa Data. Jenis-jenis hewan yang teridentifikasi dikelompokkan ke dalam tabel berdasarkan kelompok taksonnya. Potensi predator dan hama kelulut diidentifikasi menggunakan literatur yang disebutkan di atas terutama menyangkut tipe makannya. Bentuk gangguan yang mungkin ditimbulkan serta rekomendasi tindakan lebih lanjut terhadap keberadaan hewanhewan ini didiskusikan secara deskriptif. 

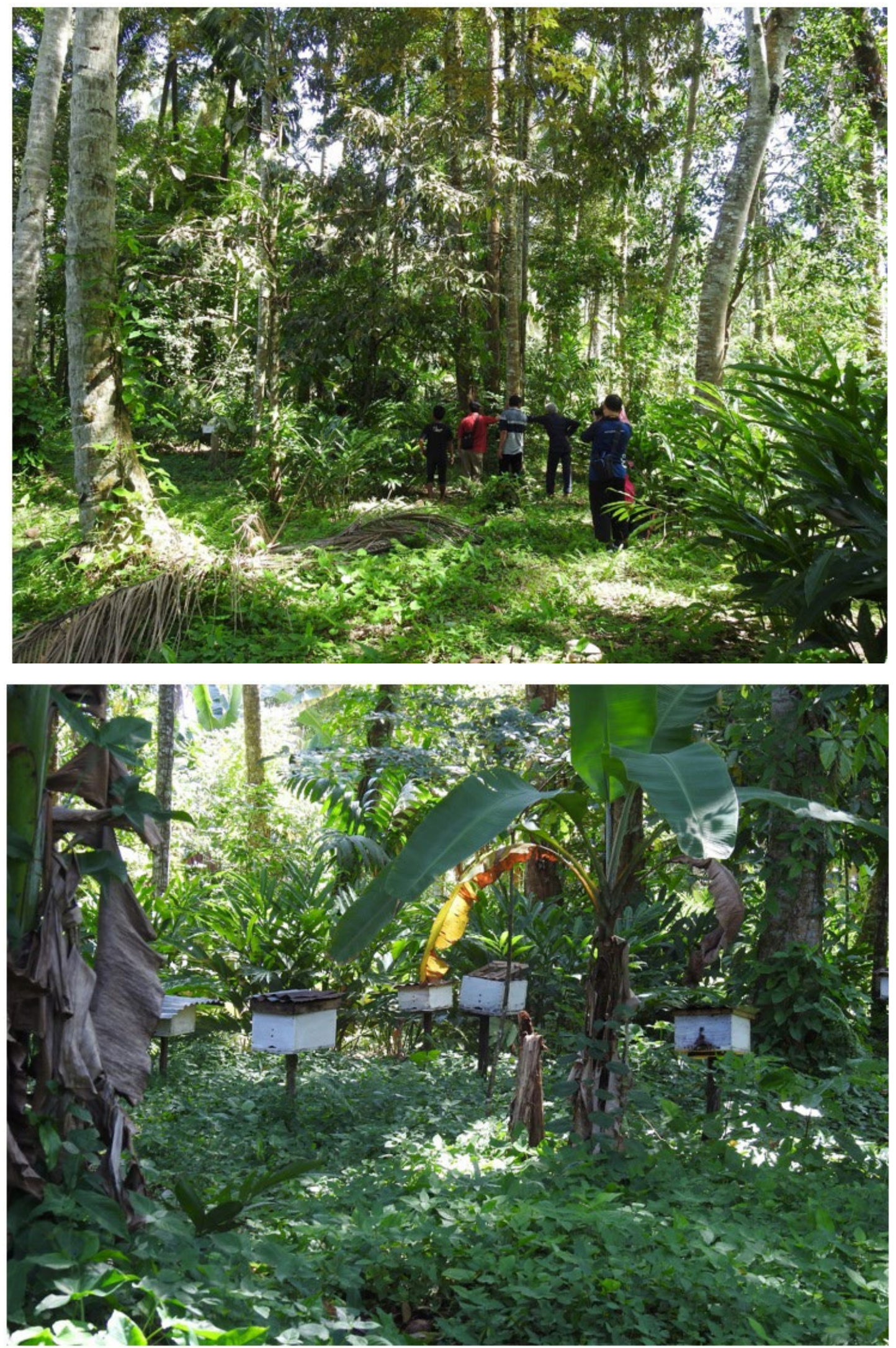

Gambar 1. Lingkungan peternakan kelulut Kelompok Tani Sakato Palak Juha (atas) dan kotak sarang yang dihuni oleh koloni kelulut (bawah) 


\section{HASIL}

Jenis-jenis Hewan Berpotensi Predator dan Hama. Pengamatan berlangsung selama lebih kurang satu setengah jam, dari pukul 14.00 sampai dengan 15.30. Walaupun singkat, pengamatan yang telah dilakukan di kawasan peternakan kelulut ini dapat mengidentifikasi setidaknya 6 jenis burung, 5 jenis capung dan 6 jenis semut (Tabel 1). Ditemukannya keberadaan hewan-hewan non-kelulut dalam observasi singkat di kawasan apiari tersebut mengindikasikan kemungkinan adanya lebih banyak lagi jenis yang belum teramati.

Keberadaan burung-burung dari kelompok petengger dan berkicau (Passeriformes) di sekitar kawasan peternakan kelulut didukung oleh lingkungan yang mempunyai naungan pepohonan yang cukup rindang. Selama pengamatan, tidak terlihat adanya kegiatan pemangsaan secara langsung oleh jenis-jenis burung tersebut terhadap kelulut yang diternakan. Dua jenis burung, Orthotomus ruficeps dan O. sericeus (Gambar 2a), merupakan pemakan serangga sejati (insectivorous) yang aktif di semak-semak. Jenis Pycnonotus goiavier dan Dicaeum trigonostigma bersifat insectivorous- frugivorous atau pemakan serangga yang juga mengkonsumsi buah-buahan, sedangkan Anthreptes malacensis bersifat insectivorous-nectarivorous yang memakan serangga dan madu bunga. Selain keberadaan individu burung, juga teramati sarang aktif dari marga Lonchura yang juga mempunyai potensi predasi tertentu terhadap kelulut (Gambar 2b).

Selain burung, kelulut juga berpotensi untuk dimangsa oleh jenis-jenis capung yang ditemukan berada di sekitar peternakan tersebut (Gambar 3a-c). Capung merupakan serangga yang bersifat predator. Terdapat lima jenis capung yang semuanya termasuk ke dalam famili Libellulidae (subordo Anisoptera) yang tercatat selama pengamatan (Tabel 1). Capung-capung ini teramati hinggap pada tumbuhan di permukaan tanah ataupun pada ranting-ranting kanopi pohon di sekitar peternakan kelulut. Selain capung, di dalam peternakan kelulut juga terdeteksi keberadaan jenis semut yaitu Odontoponera denticulata (Gambar 3d), Camponotus sp., Crematogaster sp., Nylanderia sp1, Nylanderia sp2, dan Pheidole sp. Jenis semut yang disebutkan pertama bersifat karnivora, sedangkan jenis-jenis lainnya lebih generalis dalam hal mencari makanan.

Tabel 1. Jenis-jenis hewan berpotensi predator dan hama pada peternakan kelulut

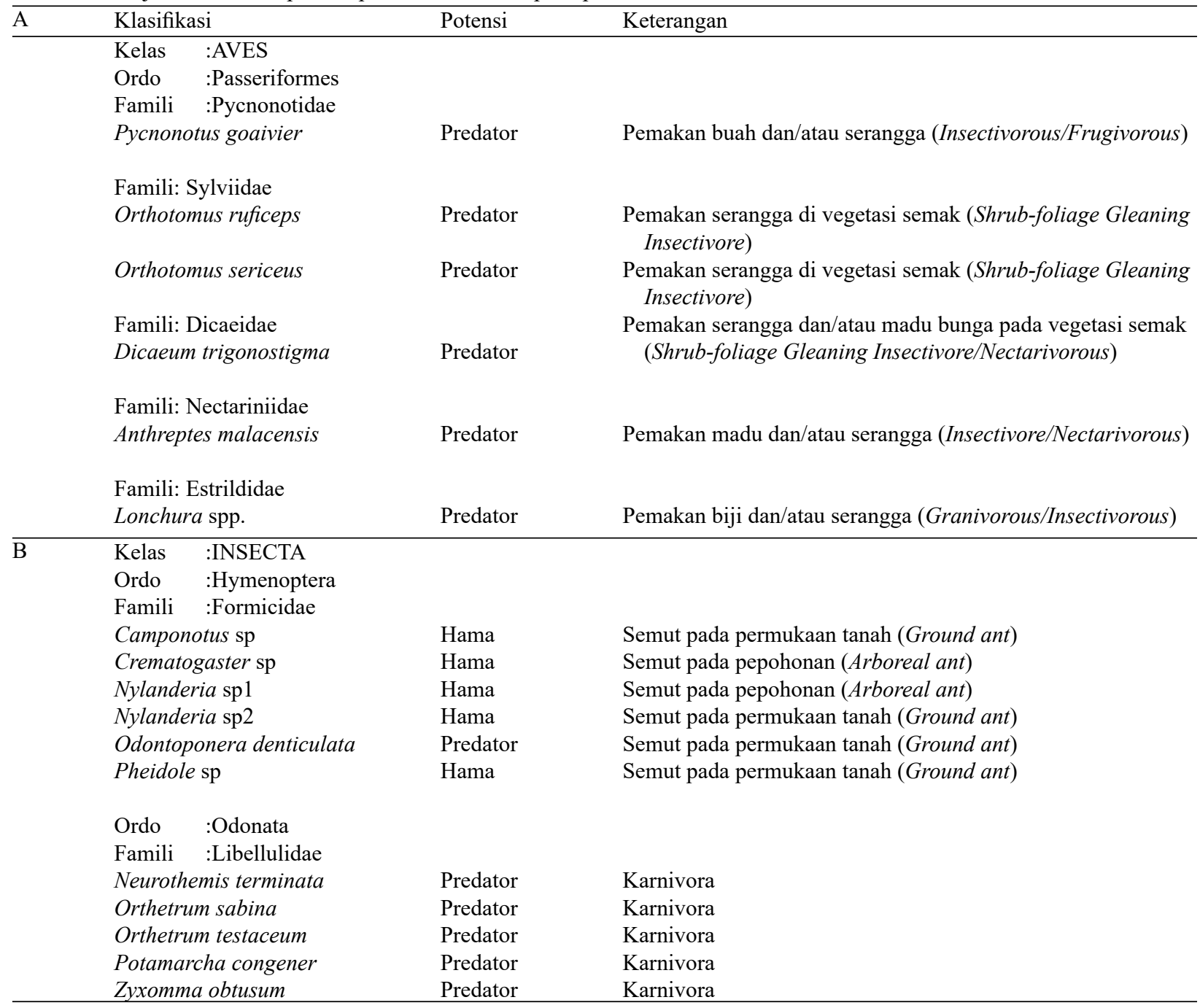



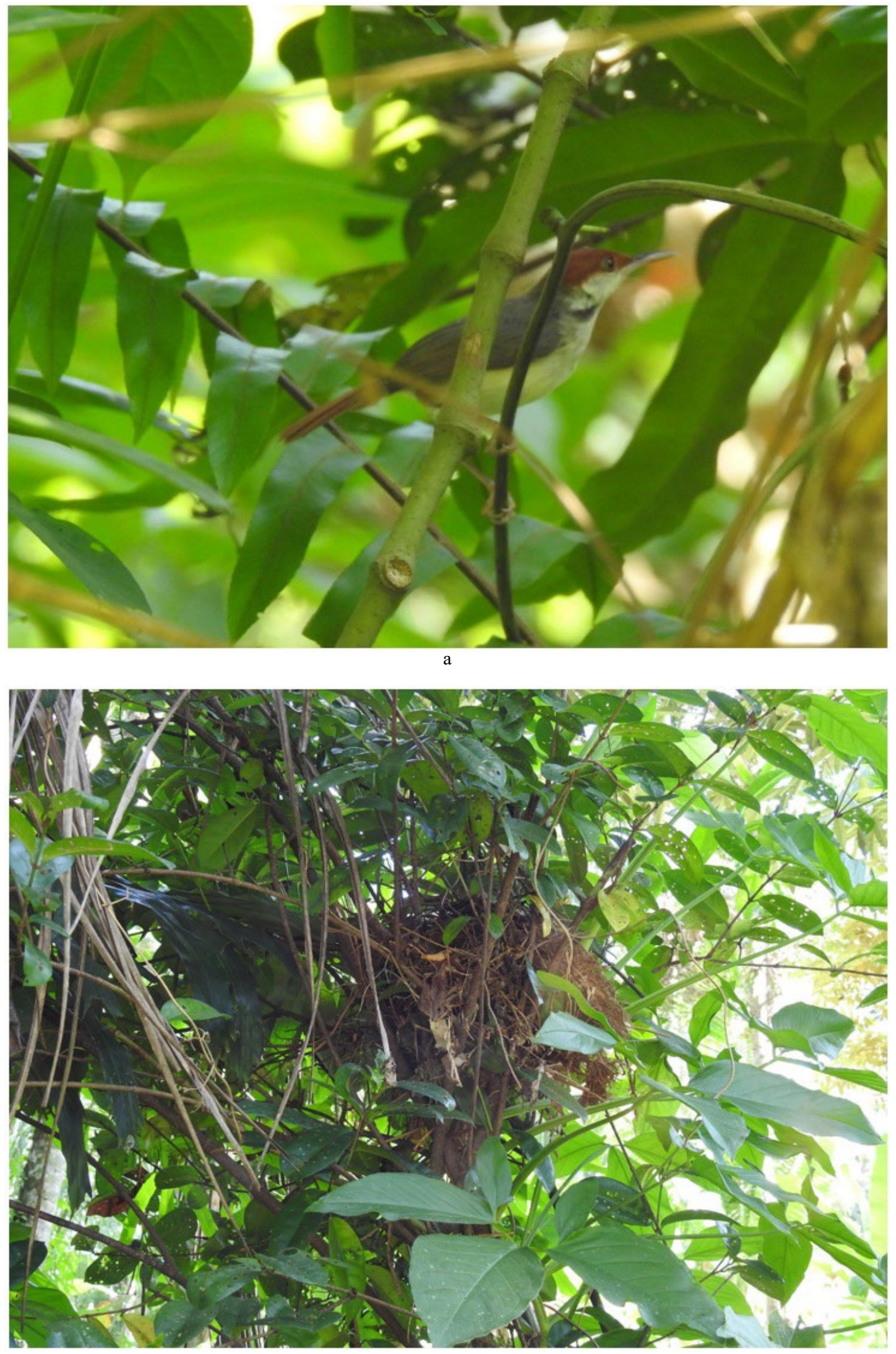

b

Gambar 2. (a) Jenis burung Orthotomus sericeus yang teramati di sekitar peternakan kelulut, (b) sarang aktif dari marga Lonchura yang ditemukan di sekitar peternakan kelulut 

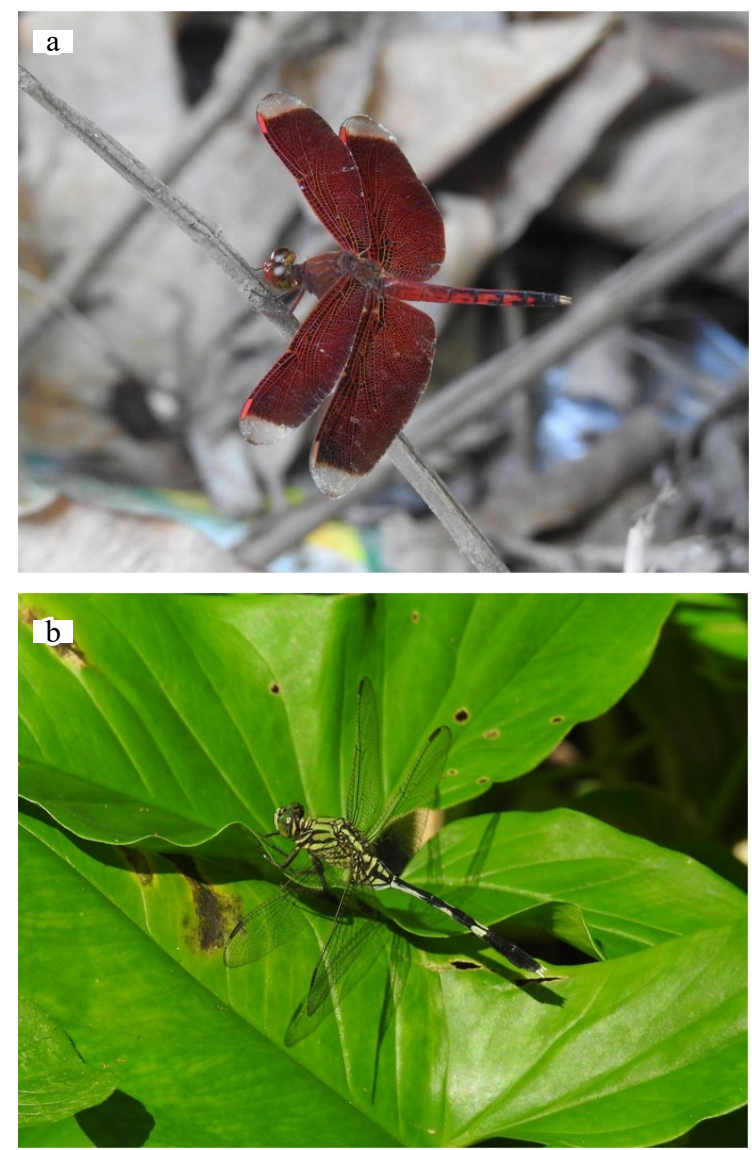
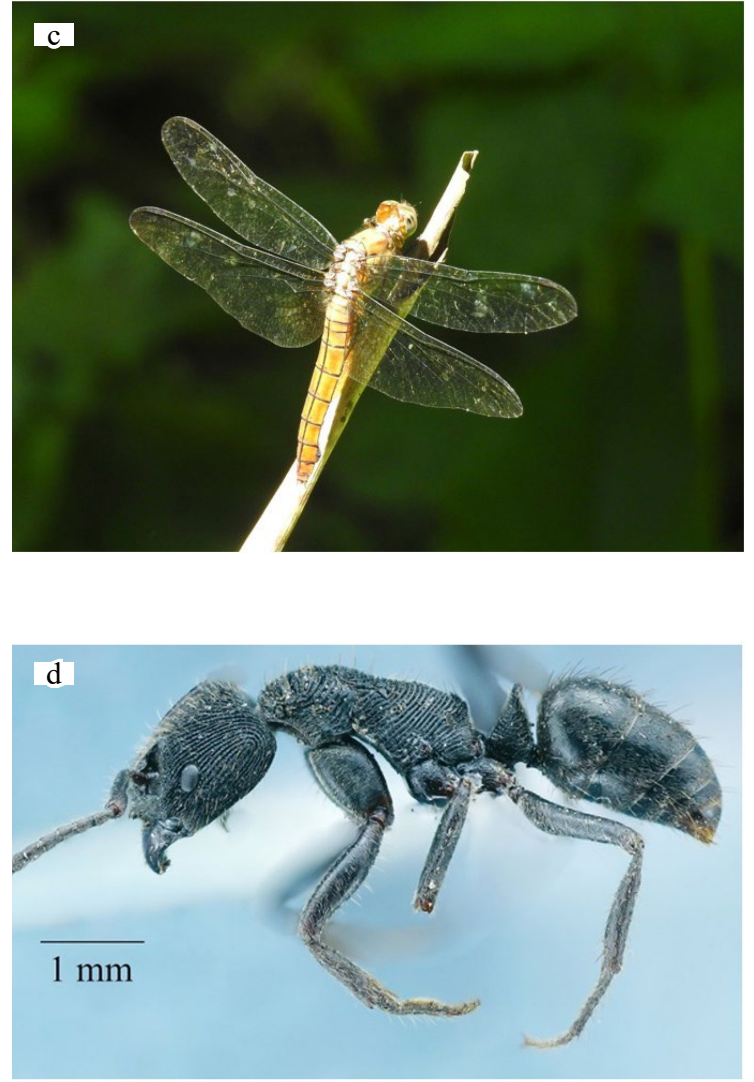

Gambar 3. Jenis-jenis serangga berpotensi predator dan hama di lokasi peternakan kelulut. Ordo Odonata: (a) Neurothemis terminata, (b) Orthetrum sabina dan (c) O. testaceum, (d) Ordo Hymenoptera: Odontoponera denticulata

\section{PEMBAHASAN}

Potensi Predasi dan Hama terhadap Koloni

Kelulut. Hymenoptera menjadi bagian dari diet non-buah bagi jenis Pycnonotus goiavier (Amit et al. 2015) yang teramati dalam penelitian ini ataupun bagi jenis Pycnonotidae lain pada umumnya (Linnebjerg et al. 2010). Serangga pada umumnya juga menjadi bagian kecil dalam makanan burungburung dari keluarga Nectariniidae, Ploceidae, dan Estrildidae (Zweers et al. 1994; Cheke et al. 2001). Jenis-jenis serangga kecil menjadi bagian dari makanan burung pemakan madu, buah atau biji-bijian ini, karena terdapat unsur-unsur seperti protein dan nutrisi tertentu yang hanya diperoleh dengan lebih baik dari sumber hewani, terutama yang berasal dari serangga yang cukup mudah untuk diserap oleh burung berukuran kecil (Diaz 1996; Kohler et al. 2010). Kebutuhan akan unsur-unsur utama dan mikronutrien akan meningkat terutama saat burung memasuki masa berbiak (Coogan et al. 2018), sehingga sangat mungkin keberadaan sumber makanan seperti koloni kelulut akan dimanfaatkan semaksimal mungkin bukan saja oleh burung-burung yang memang pemakan serangga (insectivorous), tetapi juga oleh jenis-jenis yang secara umum bukan pemakan serangga aktif. Selain itu, masa- masa pergantian bulu (moulting) merupakan saatsaat dimana burung memerlukan lebih banyak asupan protein, sehingga meningkatkan potensi pemangsaan mereka terhadap sumber-sumber protein terutama serangga (McWilliams 2008). Sarang burung Lonchura spp. yang ditemukan di semak-semak sekitar apiari mengindikasikan kenyamanan burung untuk bersarang pada lokasi yang dekat dari permukaan tanah dan kemudahan akses memperoleh makanan yang lebih mudah saat berbiak termasuk sumber mikronutrien protein yang berasal dari serangga seperti kelulut.

Famili Libellulidae mempunyai anggota jenis terbanyak di dalam bangsa capung (Odonata) dengan penyebarannya terutama pada kawasan tropis (Silsby 2001). Capung mempunyai mata majemuk yang berukuran sangat besar dan sangat sensitif, sehingga mereka dapat mendeteksi gerakan mangsanya seperti nyamuk, lalat, kutu daun, kupukupu, lebah atau capung yang berukuran lebih kecil (Setiyono et al. 2017). Capung dari famili Libellulidae ini berukuran lebih besar dari individu kelulut sehingga diperkirakan insiden pemangsaan sangat mungkin terjadi. Kemampuan pemangsaan capung berkorelasi positif dengan ukuran tubuhnya, sehingga capung-capung yang berukuran besar dapat memakan serangga mangsa yang secara 
komparatif berukuran besar atau memangsa serangga berukuran kecil dalam jumlah yang banyak (Rathod dan Parasharya 2015). Mereka umumnya akan menyergap mangsanya tersebut di udara, terutama jika kelulut terbang di sekitar tempat capung-capung ini biasa hinggap.

Semut-semut yang tercatat dalam pengamatan ini, terutama yang bersifat karnivora, secara umum hampir tidak mungkin melakukan pemangsaan terhadap individu kelulut dewasa. Lebah dan lebah tanpa sengat sebenarnya mempunyai mekanisme perilaku tersendiri yang berfungsi untuk melindungi individu dan sarang dari serangan semut (Spangler dan Taber 1970). Barubaru ini terdapat bukti pemangsaan kelulut dengan mekanisme penyergapan secara tiba-tiba oleh semut Ectatomma tuberculatum terhadap lebah tanpa sengat Tetragonisca angustula di pintu sarangnya (Ostwald et al. 2018). Kelompok serangga dari keluarga Formicidae ini sangat memungkinkan untuk menjadi hama atau setidaknya menghadirkan kompetisi terhadap koloni yang ada karena beberapa jenis semut diketahui juga mengkonsumsi nektar bunga yang menjadi makanan utama kelulut. Kemungkinan invasi dan infestasi pada kotak sarang kelulut oleh semut juga ada, walaupun kecil persentasenya. Di lain pihak, banyak jenis-jenis kelulut yang hidup berdampingan dengan semut dan rayap di alam. Kelulut memerlukan semut dan rayap untuk menciptakan lubang di pepohonan yang kemudian digunakan sebagai tempat bersarang, selain juga mengambil keuntungan dari mikroorganisme pencerna yang ada di lambung rayap (Roubik 2006; Carrijo et al. 2012). Simbiosis antara semut dan kelulut yang bersarang pada tempat yang sama dapat diamati terjadi di alam.

Inventarisasi hewan yang berpotensi sebagai predator dan penganggu bagi koloni kelulut ini melengkapi hasil yang didapatkan sebelumnya oleh Afriyanto (2015) yang mencatat sepuluh jenis hama pada peternakan lebah madu Apis cerana. Sepuluh jenis hewan ini berasal dari Kelas Arachnida, Insecta dan Reptilia. Tiga di antaranya, yaitu kalajengking Heterometrus sp. (Arachnida) serta Gehyra sp. dan Gekko sp. (Reptilia), berpotensi sebagai predator bagi lebah madu. Tentu saja, hewan-hewan ini juga berkemungkinan untuk menjadi predator atau hama bagi jenis kelulut yang berukuran jauh lebih kecil dibandingkan dengan lebah madu biasa.

Pengendalian Predator dan Hama Kelulut. Potensi predasi dan hama dari hewan-hewan yang teramati di sekitar peternakan kelulut di Kabupaten Pariaman ini didasarkan kepada prediksi dengan menggunakan sifat dan tipe makan dari masing- masing hewan tersebut yang didasarkan dari berbagai sumber bacaan. Selain itu, pengamatan ini dicuplik dari waktu lapangan yang sangat singkat (satu setengah jam) pada satu lokasi peternakan kelulut saja. Diperlukan pengamatan dalam jangka waktu yang lebih lama dengan lebih banyak lokasi sampling untuk mengetahui jenis predator dan hama pada peternakan kelulut secara lebih lengkap. Dalam jangka panjang, penelitian-penelitian ini harus mampu memperkirakan populasi hewan predator dan hama yang mengunjungi peternakan kelulut dalam jangka waktu tertentu, sehingga potensi kerugian yang diakibatkan dapat ditaksir dan tindakan pencegahan dapat diambil.

Meskipun demikian, mitigasi terhadap keberadaan hewan-hewan ini disarankan untuk dilakukan dengan tetap memperhatikan prinsipprinsip keseimbangan ekologis. Keberadaan suatu jenis organisme di dalam tingkatan rantai atau piramida makanan akan mempengaruhi keberadaan hewan di tingkatan lainnya dan secara keseluruhan keseimbangan pada suatu ekosistem (Beck 2008). Kelompok burung pemakan serangga berkemungkinan dapat memangsa capung yang bersifat predator bagi kelulut, sehingga secara tidak langsung dapat berpotensi mengurangi ancaman predasi yang diberikan oleh kelompok serangga ini. Capung juga penting sebagai pengendali serangga lain seperti nyamuk dan lalat, sehingga penting untuk mencegah penularan penyakit tertentu terhadap manusia. Pengendalian hewan-hewan predator dan hama pada peternakan kelulut, jika diperlukan, sebaiknya dilakukan dengan cara-cara yang tidak mematikan (non-lethal) hewan yang tidak diinginkan di peternakan kelulut tersebut, misalnya dengan relokasi atau menggunakan alat yang menghindarkan mereka mendekati lokasi apiari.

\section{UCAPAN TERIMA KASIH}

Penulis mengucapkan terima kasih yang sebesar-besarnya kepada kelompok tani Sakato Palak Juha, Kenagarian Lurah Ampalu, Kabupaten Padang Pariaman yang memfasilitasi pengamatan di lokasi apiari mereka. Terima kasih kepada Taufik Rahman, Teta Rahmaizi, Fithria Diniyati, Halimah Tus Sakdiah, Annisa Kamilia Amanda, dan Erni Oktavia yang membantu selama pengambilan data di lapangan. Kegiatan penelitian ini didanai oleh Hibah Publikasi dan Percepatan Guru Besar UNAND, Nomor Kontrak T/16/UN.16.17/PP.OKKRP2GB/LPPM/2019 atas nama Henny Herwina. 


\section{DAFTAR PUSTAKA}

Afriyanto U. 2015. Jenis-jenis hama pada perlebahan Apis cerana Fabr. di Patalangan Kabupaten Padang Pariaman. Jurnal Ilmiah Mahasiswa STKIP PGRI Sumatera Barat 3:1-5.

Amit B, Tuen AA, Haron K, Harun MH, Kamarudin N. 2015. The diet of Yellow-vented Bulbul (Pycnonotus goiavier) in oil palm agroecosystem. Journal of Oil Palm Research 27:417-424.

Balai Penelitian dan Pengembangan Teknologi Hasil Hutan Bukan Kayu. 2018. Panduan Singkat Budidaya dan Breeding Lebah Trigona spp. Lombok, Provinsi Nusa Tenggara Barat: Litbang Kementerian Lingkungan Hidup dan Kehutanan.

Bárta D, Dolnẏ A. 2013. Dragonflies of Sungai Wain. Ecological Field Guide to the Odonata of Lowland Mixed Dipetrocarp Forest of Southeastern Kalimantan. Czech Republic: Taita Publisher.

Beck H. 2008. Tropical Ecology. In Jergensen SE, Fath BD (Eds.). General Ecology vol. 5. Oxford: Elsevier. p. 3616-3624

Bolton B. 1994. Identification Guide to the Ant Genera of the World. Cambridge, Massachusetts: Harvard University Press.

Carrijo TF, Gonçalves RB, Santos RG. 2012. Review of bees as guests in termite nests, with a new record of the communal bee, Gaesochira obscura (Smith, 1879) (Hymenoptera, Apidae), in nests of Anoplotermes banksi Emerson, 1925 (Isoptera, Termitidae, Apicotermitinae). Insectes Sociaux 59:141-149.

Cheke RA, Mann FC, Allen R. 2001. Sunbirds. London: Christopher Helm.

Coogan SCP, Raubenheimer D, Zantis SP, Machovsky-Capuska GE. 2018. Multidimensional nutritional ecology and urban birds. Ecosphere 9:1-16.

Couvillon MJ, Wenseleers T, Imperatriz-Fonseca VL, NogueiraNeto P, Ratnieks FLW. 2007. Comparative study in stingless bees (Meliponini) demonstrates that nest entrance size predicts traffic and defensivity. Journal of Evolutionary Biology 21:194-201.

Diaz M. 1996. Food choice by seed-eating birds in relation to seed chemistry. Comparative Biochemistry and Physiology 113:239-246.

Estienne V, Mundry R, Kühl HS, Boesch C. 2016. Exploitation of underground bee nests by three sympatric consumers in Loango National Park, Gabon. Biotropica 49: 1-9.

Grüther C, Kärcher MH, Ratnieks FLW. 2011. The natural history of nest defense in a stingless bee, Tetragonisca angustula (Latreille) (Hymenoptera: Apidae), with two distinct types of entrance guards. Neotropical Entomology 40:55-61.

Haliaster. 2018. Odonata Semarang Raya. Semarang: Pecinta Alam Biologi, Universitas Diponegoro.

Hashimoto Y. 2003. Identification Guide to the Ant Subfamily of Borneo. Tools for Monitoring Soil Biodiversity in the ASEAN Region. Darwin Initiative.

Hilário SD, Imperatriz-Fonseca VL. 2003. Thermal evidence of the invasion of a stingless bee nest by a mammal. Brazilian Journal of Biology 63:457-462.

Janra MN. 2018 Inventory of dragonflies and damselflies (Odonata) in Andalas University's Limau Manis Campus Complex, Padang: Using photographical approach. Jurnal Natural 18:89-96.

Kohler A, Verburgt L, McWhorter TJ, Nicolson SW. 2010. Energy management on a nectar diet: can sunbirds meet the challenges of low temperature and dilute food? Functional ecology 24:1241-1251.

Lehmberg L, Dworschak K, Blüthgen N. 2008. Defensive behavior and chemical deterrence against ants in the stingless bee genus Trigona (Apidae, Meliponini). Journal of Apicultural Research and Bee Works 47:17-21.

Linnebjerg JF, Hansen DM, Bunbury N, Olesen JM. 2010. Diet composition of the invasive red-whiskered bulbul Pycnonotus jocosus in Mauritius. Journal of Tropical Ecology 26:347-350.
MacKinnon J, Phillips K. 1993. A Field guide to the birds of Sumatra, Java and Bali. London: Oxford University Press. MacKinnon J, Phillips K, van Balen S. 2010. Burung-Burung di Sumatera, Jawa, bali dan Kalimantan. Bogor: Puslitbang Biologi-LIPI.

McWilliams DA. 2008. Nutritional considerations for captive Charadriiformes (shorebirds, gulls and alcids). $C A B$ Reviews: Perspective in Agriculture, Veterinary Science, Nutrition and Natural Resources 3:1-8.

Manezes C, Colletto-Silva A, Gazeta GS, Kerr WE. 2009. Infestation by Pyemotes tritici (Acari, Pyemotidae) causes death of stingless bee colonies (Hymenoptera: Meliponina). Genetics and Molecular Research 8:630-634.

Michener CD. 2007. The bees of the world. Second Edition. Baltimore, USA: The John Hopkins University Press.

Ostwald MM, Ruzi SA, Baudier KM. 2018. Ambush Predation of Stingless Bees (Tetragonisca angustula) by the SolitaryForaging Ant Ectatomma tuberculatum. Journal of Insect Behavior 31:503-509.

Premila KS, Devanesan S, Shailaja KK. 2013. Reduviid bug Acanthaspis siva - a predator of honey bee and stingless be in Kerala. Insect Environment 19:197-198.

Rathod DM, Parasharya BM. 2015. Feeding potential of adult dragonflies, Pantala flavescens (Fabricius), Brachythemis contaminata Fabricius and Bradinopyga geminata Rambur (Anisoptera: LIbellulidae) on insect pests under laboratory condition. Journal of Biological Control 29:85-88.

Rizali A, Bos MM, Buchori D, Yamane S, Schulze CH. 2008. Ants in tropical urban habitat: The Myrmecofauna in a densely populated area of Bogor, West Java, Indonesia. HAYATI Journal of Biosciences 15:77-84.

Roubik DW. 2006. Stingless bee nesting biology. Apidologie 37:124-143.

Setiyono J, Diniarsih S, Oscilata ENR, Budi NS. 2017. Dragonflies of Yogyakarta. Jenis capung Daerah Istimewa Yogyakarta. Yogyakarta: Indonesia Dragonfly Society.

Sihombing DTH. 2005. Ilmu ternak lebah madu. Yogyakarta: Gajah Mada University Press.

Silsby J. 2001. Dragonflies of the World. Washington DC: Smithsonian Institution Press.

Spangler HG, Taber III S. 1970. Defensive behavior of honey bees toward ants. Psyche A Journal of Entomology 74(2): 184-189.

Sumoprastowo RM, Suprapto RA. 1980. Beternak lebah madu modern. Jakarta: PT. Bhantara Niaga Media.

Syafrizal, Bratawinata AA, Sila M, Marji D. 2012. Jenis lebar kelulut (Trigona spp.) di Hutan Pendidikan Lempake. Mulawarman Scientiffie 11:11-18.

Vijayakumar K, Muthuraman M, Jayaraj R. 2012. Predation of stingless beed (Trigona iridipennis: Apidae, Meliponinae) by centipede (Scolopendra hardwicki: Chilopoda: Scolopendramorpha). International Journal of Advanced Life Sciences 5:156-159.

Wattanachaiyingcharoen W, Jongjitvimol T. 2007. First Record of the Predator, Pahabengkakia piliceps Miller, 1941 (Reduviidae, Harpactorinae) in the Stingless Bee, Trigona collina Smith, 1857 (Apidae, Meliponinae) in Thailand. The Natural History Journal of Chulalongkorn University 7:71-74.

Wielgoss A, Tscharntke T, Buchori D, Fiala B, Clough Y. 2010. Temperature and a dominant Dolichorine ant species affect ant diversity in Indonesian cacao plantations. Agriculture, Ecosystem and Environment 135:253-259.

Zweers GA, Berkhoudt H, Vanden Berge JC. 1994. Behavioral Mechanisms of Avian Feeding. Advances in Comparative and Environmental Physiology. In Bels VL, Chardon M, Vandewalle P (Eds.). Comparative and Environmental Physiology 18 -Biomechanics of Feeding in Vertebrates. Heidelberg: Springer Link. p. 241-279. 